\title{
KELURAHAN UBUD DI AMBANG KEMACETAN TOTAL
}

Wisnu Pramudya a, 1 , I Nyoman Sukma Arida a, 2

1pramudyawisnu@hotmail.co.id, 2sukma.arida@gmail.com

a Program Studi S1 Destinasi Pariwisata,Fakultas Pariwisata,Universitas Udayana, Jl. Dr. R. Goris, Denpasar, Bali 80232 Indonesia

\section{ABSTRACT}

Traffic congestion in the distric of Ubud is an urgent problem. It is a logical consequence of the unpreparedness of Ubud in the face of rapid development of tourism. Construction of facilities and infrastructure provided for tourists, continuously carried out without analyzing the carrying capacity of Ubud as a tourism destination. The failure of governement authorities in managing public space in Ubud led to the emergence of traffic congestion. The purpose of this research is to find out the cause of traffic congestion as well as the action is being pursued by local community in solving traffic congestion.

In this research, there are quantitative and qualitative data derived from primary and secondary data. The techniques to collect data were using observation, in-depth interview and literature study. Informants were determined by choosing the first informant, followed by key informants. The data obtained was analyzed using qualitative method and explained descriptively.

Research shows the factors causing traffic congestion in the distiric of Ubud are emerged directly by two categories, internal and external categories. Local community managed to solve congestion with the realization of two central parkings, shuttle bus, traffic management and revitalization of pedestrian and traffic signs. Without real action from local government, local community have tried to solve traffic congestion with their own resources and ideas.

Keywords: traffic congestion, local community.

\section{PENDAHULUAN}

\subsection{Latar Belakang}

Kemacetan lalu lintas yang terjadi di Kelurahan Ubud seperti sebuah novel yang tidak memiliki akhir cerita. Baik masyarakat maupun pemerintah terlihat dibuat bingung memikirkan bagaimana cara menyelesaikan permasalahan ini. Pariwisata sebagai ibu dari semua anak permasalahan, seakan dibuat tidak berkutik melihat seluruh carut-marut pembangunan di Ubud. Masyarakat sebagai pencipta, masyarakat juga yang menjadi korban.

Pariwisata yang konon akan membawa keberkahan, memang meningkatkan kesejahteraan masyarakat dan menciptakan banyak lapangan pekerjaan. Namun, masyarakat tidak pernah menyadari bahwa pariwisata juga akan membawa permasalahan sosial. Kemacetan memberikan banyak dampak negatif bagi banyak segi kehidupan masyarakat lokal. Ubud yang pada mulanya begitu tenang dan damai, saat ini terusik oleh riuh suara kendaraan dan wisatawan.

Kemacetan lalu lintas yang terjadi di Kelurahan Ubud merupakan konsekuensi logis atas ketidaksiapan Ubud dalam menghadapi perkembangan pariwisata yang pesat. Ubud telah bertransformasi dari sebuah desa kecil agraris menjadi magnet pariwisata di Bali yang berkelas internasional. Pembangunan sarana dan prasarana yang disediakan bagi wisatawan, terus menerus dilakukan tanpa menganalisa terlebih dahulu besarnya daya tampung Ubud sebagai daerah tujuan wisata. Kegagalan pemerintah setempat dalam menata ruang publik di Ubud telah berakibat fatal, bibit dari kegagalan tersebut sudah terlihat, salah satunya yaitu munculnya kemacetan lalu lintas.

Dampak dari kemacetan lalu lintas memang tidak dirasakan langsung oleh pemerintah. Ubud masih terus menjadi penyumbang terbesar bagi kas daerah, tiap tahun nilainya hampir $70 \%$ dari total keseluruhan pemasukan yang diterima dari seluruh daerah yang ada di Kabupaten Gianyar. Di satu sisi, masyarakat lokal setiap hari harus memboroskan bahan bakar, kehilangan waktu, dan mengalami masalah psikologis akibat dari kemacetan lalu lintas yang terjadi. Kemegahan industri pariwisata di Ubud yang menjadi mesin perekonomian daerah seakan menyimpan bom waktu berisi segudang permasalahan yang dapat meledak kapan saja.

Namun, minimnya kehadiran pemerintah dalam mengatasi masalah kemacetan lalu lintas di Kelurahan Ubud ternyata menumbuhkan inisiatif dari masyarakat lokal. Munculnya 
berbagai tokoh intelektual dari elemen masyarakat mulai menyuarakan kegelisahan mereka akan pariwisata Ubud. Masyarakat sadar bahwa pariwisata telah memberikan kesejahteraan bagi mereka, jadi apabila masalah tersebut tidak segera diselesaikan, mereka khawatir akan dampak yang ditimbulkannya yaitu wisatawan mulai meninggalkan Ubud. Karena wisatawan merupakan bahan bakar dari mesin perekonomian Ubud, tanpa kehadiran mereka sudah dapat dipastikan bahwa kegiatan pariwisata di Ubud akan lumpuh.

Kemacetan lalu lintas telah menjadi pemandangan sehari-hari masyarakat lokal, di beberapa ruas jalan di Kelurahan Ubud banyak terjadi antrian panjang kendaraan yang seakan membuat manusia enggan untuk melakukan aktifitas di luar. Kelurahan Ubud seakan di ambang pintu kemacetan total yang dengan mudah mengancam eksistensi pariwisatanya. Seharusnya kemacetan tidak dipandang sebagai suatu keniscayaan, sehingga solusi tetap harus dipikirkan sehingga kemacetan tidak lagi menjadi momok bagi pariwisata.

Karakteristik sosial masyarakat dan kondisi lingkungan Ubud yang berbeda dari kebanyakan daerah tujuan wisata yang ada di Bali, memerlukan suatu pendekatan yang berbeda dalam mencari solusi masalah kemacetan. Apabila permasalahan tersebut tidak segera diselesaikan, maka akan menjadi bumerang yang pada akhirnya dapat mengancam eksistensi pariwisata di Ubud.

\subsection{Rumusan Masalah}

a. Apa faktor-faktor penyebab kemacetan lalu lintas di Kelurahan Ubud?

b. Bagaimana upaya masyarakat lokal dalam rangka mengatasi kemacetan lalu lintas di Kelurahan Ubud?

\subsection{Tujuan dan Manfaat Penelitian}

a. Tulisan ini bertujuan untuk mengetahui faktor-faktor penyebab kemacetan lalu lintas di Kelurahan Ubud serta mengetahui upaya masyarakat lokal dalam mengatasi permasalahan tersebut.

b. Tulisan ini bermanfaat secara akademis, untuk menambah wawasan dan pengetahuan dalam penerapan teori integrasi sosial pada dinamika sosial yang ada di masyarakat secara umum. Kemudian bermanfaat bagi masyarakat lokal, dalam membantu mengidentifikasi penyebab kemacetan serta mencari solusi yang lebih efektif dalam mengatasi kemacetan lalu lintas di Kelurahan Ubud.

\section{TINJAUAN PUSTAKA}

\subsection{Tinjauan Penelitian Sebelumnya}

Terdapat dua penelitian terkait kemacetan lalu lintas yang sesuai dengan topik dalam penelitian ini. Penelitian pertama berjudul "Analisis Kebijakan Penanganan Kemacetan Lalu Lintas di Jalan Teuku Umar Kawasan Jatingaleh Semarang", oleh Feby Anisia Purnama Sari pada tahun 2011 yang berlokasi di Semarang, memiliki fokus penelitian yaitu menemukan alternatif kebijakan yang tepat dalam mengatasi kemacetan lalu lintas di daerah tersebut. Penelitian kedua berjudul "Implementasi Kebijakan Program Trans Jakarta/Busway Dalam Rangka Mengurangi Kemacetan di DKI Jakarta", oleh Dessy Budiyanti pada tahun 2012 yang berlokasi di DKI Jakarta, memiliki fokus penelitian yaitu implementasi kebijakan program Busway atau Trans Jakarta dalam rangka mengurangi kemacetan lalu lintas di daerah tersebut. Sedangkan pada penelitian sekarang, memiliki fokus penelitian pada upaya yang dilakukan masyarakat lokal dalam mengatasi kemacetan lalu lintas di Kelurahan Ubud.

\subsection{Landasan Konsep dan Teori}

a. Konsep Kemacetan Lalu Lintas

Menurut MKJI (1997) kemacetan adalah kondisi dimana arus lalu lintas yang lewat pada ruas jalan yang ditinjau, melebihi kapasitas rencana jalan tersebut yang mengakibatkan kecepatan kendaraan yang melintas mendekati atau sama dengan $0 \mathrm{~km} / \mathrm{jam}$, sehingga menyebabkan terjadinya kemacetan.

Menurut Boediningsih (2011) kemacetan lalu lintas terjadi karena beberapa faktor, seperti banyak pengguna jalan yang tidak tertib, pemakai jalan melawan arus, kurangnya petugas lalu lintas yang mengawasi, adanya mobil yang parkir di badan jalan, permukaan jalan tidak rata, tidak ada jembatan penyeberangan, dan tidak ada pembatasan jenis kendaraan. Banyaknya pengguna jalan yang tidak tertib, seperti adanya pedagang kaki lima yang berjualan di tepi jalan, dan parkir liar. Selain itu, ada pemakai jalan yang melawan arus. Hal ini terjadi karena kurangnya jumlah petugas lalu lintas dalam mengatasi jalannya lalu lintas terutama di jalan-jalan yang rawan macet.

Konsep Masyarakat Aktif 
Menurut Etzioni (dalam Poloma, 2010) masyarakat aktif adalah masyarakat yang menguasai dunia sosialnya. Mereka sangat berbeda dengan masyarakat pasif dimana para anggotanya dikendalikan oleh kekuatan-kekuatan luar atau kekuatan aktif lainnya. Masyarakat aktif mampu mengidentifikasi dinamika-dinamika yang terjadi di lingkungannya. Melalui sekolompok intelektual dalam masyarakat, yang memiliki pengetahuan yang baik, mereka mampu mencari jalan keluar atau solusi atas dinamika yang ada.

c. Konsep Koordinasi

Menurut Handoko (2003) koordinasi merupakan suatu sistem dan proses interaksi untuk mewujudkan keterpaduan, keserasian, dan kesederhanaan berbagai kegiatan inter dan antar institusi-institusi di masyarakat melalui komunikasi dan dialog-dialog antar berbagai individu.

Sedangkan Menurut Stoner dan Wankel (1986) koordinasi adalah proses menyatupadukan tujuan-tujuan dan kegiatankegiatan dari unit-unit (bagian-bagian atau bidang-bidang fungsional) suatu organisasi yang terpisah untuk mencapai sasaran-sasaran organisasi secara efisien.

\section{d. Konsep Sinergi}

Menurut Deardorff dan Williams (2006) sinergi adalah sebuah proses dimana interaksi dari dua atau lebih agen atau kekuatan akan menghasilkan pengaruh gabungan yang lebih besar dibandingkan jumlah dari pengaruh mereka secara individual. Konsep sinergi pada prinsipnya bahwa, di dalam mencapai suatu tujuan, usaha yang dilakukan secara tersistem dan bersama-sama hasilnya akan lebih besar dibandingkan dengan secara sendiri-sendiri.

e. Teori Manajemen Lalu Lintas

Menurut Priyanto (2010) terdapat dua manajemen lalu lintas yang mampu digunakan untuk mengatasi permasalahan yang berkaitan dengan kemacetan lalu lintas. Manajemen yang pertama adalah manifestation problems atau permasalahan yang kita lihat sehari-hari, sedangkan yang kedua adalah root problems atau penyelesaian yang terkait dengan akar permasalahan. Untuk itu, upaya penanganan kemacetan lalu lintas dilihat dari masalah yang terjadi sehari-hari adalah:

1. Membatasi kecepatan kendaraan
2. Menambah fasilitas pejalan kaki dan tempat parkir.

3. Menambah rambu, marka dan papan petunjuk.

4. Menerapkan jalan satu arah

5. Perbaikan kondisi simpang

6. Pemisahan sepeda motor

7. Pemisahan kendaraan tidak bermotor

Sedangkan upaya penanganan kemacetan lalu lintas dilihat dari akar permasalahannya adalah:

1. Pengaturan jam sibuk

2. Meningkatkan okupansi kendaraan

3. Mengurangi kebutuhan perjalanan

4. Mengurangi panjang perjalanan

\section{METODE PENELITIAN}

\subsection{Ruang Lingkup Penelitian}

Penelitian ini berlokasi di Kelurahan Ubud, Kabupaten Gianyar. Namun difokuskan terhadap dua desa pekaraman yaitu Desa Ubud dan Desa Padangtegal sebagai desa yang paling besar terkena dampak kemacetan lalu lintas. Batasan dalam penelitian ini yaitu:

a. Faktor-faktor yang dimaksud adalah penyebab kemacetan lalu lintas yang dipilah ke dalam dua kategori yaitu kategori internal dan kategori eksternal.

b. Upaya yang dimaksud adalah segala bentuk tindakan atau solusi yang sudah direalisasikan (termasuk yang sedang berjalan/dikerjakan) oleh masyarakat lokal dalam rangka mengatasi kemacetan lalu lintas.

\subsection{Teknik Pengumpulan Data dan Teknik Analisi Data}

Penilitian ini merupakan penelitian kualitatif. Data dalam penelitian ini bersumber dari data primer dan data sekunder. Data primer dalam penelitian ini adalah faktor-faktor penyebab kemacetan lalu lintas dan upaya yang dilakukan masyarakat lokal dalam mengatasi kemacetan lalu lintas di Kelurahan Ubud. Sedangkan data sekunder diantaranya adalah profil Kelurahan Ubud, data statistik, dan informasi lain yang berasal dari media digital.

Untuk memperoleh data primer, teknik pengumpulan data menggunakan observasi dan wawancara mendalam. Observasi dilakukan langsung pada objek penelitian yaitu kemacetan yang sedang terjadi di Kelurahan Ubud. Sedangkan wawancara mendalam dilakukan dengan informan yang memiliki kriteria yaitu 
pegetahuan dan informasi luas mengenai masalah kemacetan. Teknik penentuan informan dimulai dengan menentukan informan pangkal, yang kemudian dilanjutkan dengan informan kunci. Dalam penelitian ini, informan pangkal adalah Camat Ubud. Sedangkan informan kunci adalah elite desa, tokoh puri, tokoh intelektual, FKDPU, pecalang yang berasal dari Desa Ubud dan Desa Padangtegal, serta Kepolisian Sektor Ubud dan Dishub, Infokom Kabupaten Gianyar.

Kemudian data yang diperoleh dianalisis secara deskriptif kualitatif dengan langkahlangkah yaitu reduksi data, penyajian data dan penarikan kesimpulan serta verifikasi.

\section{HASIL DAN PEMBAHASAN.}

\subsection{Fenomena Kemacetan dan} Faktor-faktor Penyebabnya

Kemacetan yang terjadi di Kelurahan Ubud bukanlah suatu permasalahan baru. Kondisi kemacetan yang semakin memburuk merupakan buah dari bibit yang sudah ditanam sendiri baik oleh pemerintah daerah maupun masyarakat lokal sejak beberapa dekade kebelakang. Kemacetan tersebut mulai muncul ke permukaan sejak booming pariwisata di Ubud sekitar tahun 1970 an. Pada waktu itu, Ubud yang semakin dikenal oleh wisatawan mancanegara karena menjadi pusat seni dan budaya di Bali, otomatis dengan meningkatnya kunjungan wisatawan setiap tahunnya, diperlukan juga fasilitas untuk menunjang kebutuhan wisatawan.

Pembangunan fasilitas-fasilitas pariwisata mulai dilakukan, hotel dan restoran mulai bermunculan satu-persatu, bahkan apabila ditinjau dari sejarah kemunculan hotel pertama di Ubud, Hotel Campuhan sudah berdiri sejak sekitar tahun 1928. Dengan aktifnya pembangunan yang dilakukan baik oleh pemerintah daerah dan masyarakat tersebut, maka masyarakat lokal yang pada umumnya memiliki rmata pencaharian sebagai pelukis dan petani, mulai ikut terjun menjadi pelaku pariwisata, terutama para pemuda pada saat itu.

Untuk menunjang kemampuan manusianya, mulai juga dibangun sekolah-sekolah di Ubud. Keluarga puri Ubud merupakan salah satu kelompok yang berperan dominan dalam perkembangan pariwisata di Ubud. Beberapa sekolah mulai dari dasar hingga menengah yang sampai saat ini masih berdiri, tidak lain juga berkat pengaruh dan sumbangasih dari keluarga puri. Puri Ubud selain sebagai ikon pariwisata di Ubud juga memiliki manfaat yang besar bagi kehidupan sosial masyarakat lokal.

Seiring berjalannya waktu, maka sekitar awal tahun 1990 sampai 2000 adalah salah satu titik dimana Ubud benar-benar bertransformasi dari desa agraris menjadi desa internasional yang berbasis industri pariwisata. Pembangunan fasilitas pariwisata terus menerus dilakukan, tanpa melihat kapasitas dan daya tampung Ubud. Banyak rumah-rumah warga yang beralih fungsi menjadi tempat usaha yang diperuntukkan untuk menunjang kebutuhan wisatawan dan meraup pundi-pundi ekonomi.

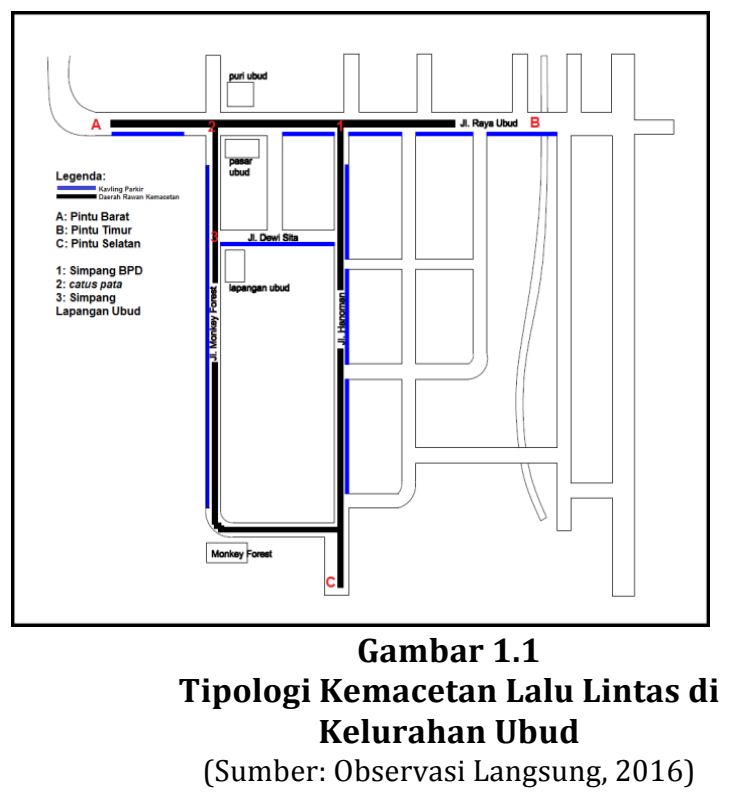

Saat ini, kemacetan yang terjadi di Kelurahan Ubud terlihat sudah berada di puncaknya. Pada siang hari sekitar pukul 13.00 16.00 merupakan waktu rawan kemacetan sehingga hampir di seluruh ruas jalan di walayah Kelurahan Ubud memiliki kondisi yang sama. Antarian kendaraan yang mengular, diiringi oleh kegiatan pariwisata dan aktifitas masyarakat setempat. Bahkan sekelompok masyarakat membuat suatu organisasi yaitu "Ubud Tolak Bis Besar" sebagai respon atas permasalahan dan betapa kemacetan telah merugikan masyarakat lokal, selain itu disatu sisi wisatawan juga merupakan korban tambahan dari permasalahan yang tak kunjung terselesaikan ini.

Kemacetan sendiri sebabkan langsung oleh beberapa faktor yang dipilah dalam dua kategori yaitu kategori internal dan eksternal. Dalam kategori internal faktor-faktor tersebut adalah:

\section{a. Perkembangan Pariwisata}


Perkembangan pariwisata di Ubud yang pesat Dapat dikatakan merupakan salah satu akar permasalahan dari kemacetan yang sedang terjadi. Perkembangan tersebut ditandai dengan meningkatnya jumlah kunjungan wisatawan, pembangunan sarana dan prasarana pariwisata yang terus menerus, serta banyaknya kegiatan pariwisata yang disediakan bagi wisatawan. Hal ini juga menyebabkan banyaknya masyarakat yang terjun menjadi pelaku pariwisata.

Menurut penuturan salah satu tokoh intelektual Desa Padangtegal yaitu I Nyoman Buana:

"Desa Ubud semula merupakan desa agraris yang sebagain besar masyarakatnya merupakan petani. Kemudian pada sekitar awal tahun 1970 an, kegiatan pariwisata mulai berkembang dan semakin pesat pada akhir tahun 2000 an. Namun, interaksi masyarakat Ubud dengan wisatawan mancanegara sudah dilakukan sejak awal tahun 1930, dimana pada waktu itu beberapa pelukis besar seperti Rudolf Bonnet dan Walter Spies mengunjungi Ubud dan disambut baik oleh pihak puri."

Penuturan dari I Nyoman Buana diperkuat oleh salah satu tokoh intelektual Desa Ubud yaitu I Ketut Suardana:

"Apabila kita berkunjung ke salah satu rumah di Ubud, sebelum kegiatan pariwisata ada. Maka yang kita temukan adalah orang yang sedang melukis, begitu juga rumah-rumah yang lain. Hampir di setiap rumah yang ada di Ubud memiliki pelukis dengan karakternya masing-masing. Namun saat ini, apabila kita berkunjunga ke salah satu rumah masyarakat, yang kita temui adalah tokoh, cafe dan usaha pariwisata lainnya."

Baik dari penuturan kedua informan, sejalan dengan realita yang ada di Kelurahan Ubud. Perkembangan pariwisata juga dapat dilihat dengan beralih fungsinya rumah warga yang menjadi tempat usaha. Di sepanjang Jalan Hanoman, Jalan Monkey Forest, dan Jalan Raya Ubud hampir keseluruhan rumah warga sudah beralih fungsi, kebanyakan adalah tempat usaha seperti restoran, toko, cafe dan sebagainya. Maka, hal ini tidak mengejutkan sama sekali apabila kemacetan yang terjadi di Kelurahan Ubud tidak lain bersumber dari adanya kegiatan pariwisata.

\section{b. Pusat Kegiatan Sosial, Ekonomi, dan Politik}

Penyebab kedua adalah selain Kelurahan Ubud menjadi pusat kegiatan pariwisata, di satu sisi juga merupakan pusat kegiatan sosial, ekonomi, dan politik. Sehingga Ubud menjadi semakin padat dengan adanya berbagai kegiatan.

Menurut penuturan tokoh intelektual Desa Padangtegal yaitu I Kadek Gunarta:

"Ubud menjadi desa yang sangat padat akibat dari kegiatan pariwisata, pemerintahan, dan sektor bisnis yang berada di pusat Ubud. Hal ini disayangkan karena masih banyak daerah lain yang lebih sepi. Akibatnya seluruh kegiatan masyarakat dan wisatawan ada di Ubud, jumlah kendaraan yang ada termasuk dengan masyarakat yang berasal dari luar Ubud menjadi bertambah sehingga kemacetan semakin sulit untuk diuraikan."

Penuturan tersebut diperkuat oleh tokoh intelektual Desa Padangtegal lainnya yaitu I Nyoman Buana:

"Ruas jalan Ubud yang sempit tidak bisa menampung jumlah kendaraan wisatawan yang akan berwisata dan kendaraan masyarakat yang akan bekerja. Belum lagi jumlah pekerja yang berasal dari luar Ubud juga tidak sedikit. Secara langsung mereka juga menambah beban jalan dan berkontribusi pada kemacetan di Ubud."

Dari penuturan kedua informan, dapat diketahui bahwa saat ini implementasi kebijakan tata ruang di Kelurahan Ubud memang tidak begitu jelas. Mulai dari kantor pemerintahan, kantor perusahaan seperti bank, ekspor dan impor, pasar dan lain sebagainya menumpuk menjadi satu.

Seharusnya, Ubud sebagai daerah pariwisata lebih difokuskan untuk kegiatan pariwisata saja. Padahal, masih banyak daerah lain yang lebih sepi di lingkungan Kelurahan Ubud yang dapat digunakan sebagai relokasi kantor-kantor tersebut, agar kepadatan di Ubud dapat berkurang dan akhirnya berdampak pada berkurangnya aktifitas lalu lintas di daerah rawan kemacetan.

\section{c. Rendahnya Kesadaran Pengguna Jalan}

Rendahnya kesadaran baik dari masyarakat lokal, pendatang dan wisatawan seperti pelanggaran rambu-rambu lalu lintas, memarkir kendaraan di badan jalan dan di sembarang tempat, serta melawan arus kendaraan merupakan salah satu penyebab kemacetan.

Rambu-rambu lalu lintas merupakan salah satu upaya yang dilakukan untuk mengurangi kemacetan lalu lintas di Kelurahan Ubud. Ramburambu tersebut digunakan agar pengguna jalan lebih tertib dan bertanggung jawab. Pengguna jalan yang tertib dan tidak melanggar rambu- 
rambu lalu lintas akan membantu mengurangi kemacetan lalu lintas di Kelurahan Ubud.

Rambu-rambu lalu lintas yang di Ubud diantaranya adalah rambu-rambu dilarang parkir, dilarang berhenti, dan jalan satu arah. Tidak ada data pasti berapa jumlah pelanggar untuk tiap rambu-rambu lalu lintas yang ada. Namun sebagai contoh ketika jalan satu arah digunakan atau dilanggar oleh pengguna jalan maka akan ada tambahan beban jalan yang otomatis mengurangi luas jalan yang digunakan.

Pengguna jalan yang melanggar rambu dilarang parkir dan memarkir kendaraannya di badan jalan otomatis juga akan mengurangi ruas jalan yang ada, terlebih lagi pengguna jalan sering memarkir kendaraanya di tempat-tempat yang justru merupakan titik kemacetan. Selain itu rambu dilarang berhenti yang dilanggar oleh pengguna jalan menyebabkan antrian kendaraan, apabila kendaraan tersebut berhenti terlalu lama sering kali antrian kendaraan semakin mengular.

\section{d. Parkir Kendaraan di Badan Jalan}

Penyebab pertama kemacetan di Ubud adalah banyaknya kendaraan baik roda empat dan roda dua yang parkir di badan jalan. Menurut Kepala Dishub, Infokom Kabupaten Gianyar yaitu Cokorda Agusnawa:

"Kavling-kavling parkir tersebut merupakan permintaan desa adat sebagai respon atas tidak adanya kantong parkir di Ubud yang semula tujuannya hanya diperuntukkan untuk wisatawan. Namun sayangnya banyak masyarakat, pemilik toko dan penyedia jasa sewa transport memanfaatkan lahan tersebut sebagai parkir harian kendaraan mereka."

Penuturan tersebut diperkuat oleh Bendesa Desa padangtegal yaitu I Made Gandra:

"Memang kavling parkir, khususnya di wilayah Desa Padangtegal merupakan inisiatif masyarakat untuk menampung kendaraan yang masuk karena sulitnya mencari tempat parkir di Ubud. Sayangnya, banyak kendaraan yang diparkir justru bukanlah milik wisatawan, namun milik warga, pemilik dan pegawai toko akibat mereka tidak memiliki garasi."

Dari penuturan kedua informan, dapat diketahui bahwa kavling parkir yang ada di banyak ruas jalan di Kelurahan Ubud peruntukkannya bukan untuk masyarakat umum, namun untuk wisatawan. Pengelolaan yang tidak baik serta minimnya pengawasan menyebabkan semua orang dapat memarkir kendaraannya dengan bebas. Padahal, parkir kendaraan di badan jalan ini menyebabkan beban jalan bertambah dan kapasitas jalan menjadi berkurang.

Berikut adalah jumlah kendaraan yang diparkir di beberapa ruas jalan, saat dilakukan penghitungan kemacetan lalu lintas sedang terjadi. Dari tabel 1.1, dapat diketahui bahwa jumlah kendaraan baik roda empat dan roda dua yang diparkir di badan jalan cukup banyak.

Tabel 1.1

Jumlah Kendaraan Parkir di Badan Jalan

\begin{tabular}{|c|l|r|r|}
\hline No & Nama Jalan & Roda 4 & Roda 2 \\
\hline 1 & Jalan Raya Ubud & 114 & 717 \\
\hline 2 & Jalan Dewi Sita & 37 & 316 \\
\hline 3 & Jalan Hanoman & 89 & 570 \\
\hline 4 & Jalan Monkey Forest & 166 & 1151 \\
\hline & Jumlah & 406 & 2754 \\
\hline
\end{tabular}

Sumber: Observasi Langsung, 2016

Dari gambar 1.1, apabila dilakukan perbandingan maka dapat diketahui bahwa daerah rawan kemacetan di Kelurahan Ubud memiliki pola yang sama dengan lokasi kavling parkir tersebut. Terdapat korelasi antara kemacetan yang sedang terjadi dengan banyaknya kendaraan yang parkir di badan jalan.

\section{e. Peningkatan Volume Kendaraan}

Ketika aktifitas kendaraan yang masuk ke Kelurahan Ubud meningkat, sedangkan jumlah kendaraan yang keluar lebih sedikit, akibatnya terjadi penumpukan kendaran. Hal ini belum lagi ditambah dengan banyaknya kendaraan yang diparkir di badang jalan, akibat ruas jalan yang ada tidak mampu mengimbangi jumlah kendaraan yang masuk, terjadilah kemacetan lalu lintas.

Untuk mengetahui apakah terjadi peningkatan volume kendaraan pada jam sibuk dan untuk mengetahui seberapa besar peningkatan volume tersebut. Maka penulis melakukan penghitungan jumlah kendaraan yang masuk dan keluar Ubud di setiap pintu masuk yang ada. Di sebelah selatan yaitu Jalan Pengosekan, di sebelah timur yaitu Jalan Raya Ubud dan di sebelah barat yaitu Jalan Raya Campuhan. Untuk lebih jelasnya dapat dilihat pada gambar 1.1.

Penghitungan volume kendaraan dilakukan dengan membandingkan jumlah kendaraan pada pagi hari yaitu pukul 09.00 - 09.45 dengan jumlah kendaraan pada siang hari yaitu pukul 13.00 - 13.45. Penghitungan volume kendaraan dilakukan sebanyak 3 x 15 menit. Penghitungan volume kendaraan dilakukan satu minggu sebelum Tahun Baru 2016 yaitu pada tanggal 23 
Desember 2015 dan satu minggu setelah Tahun Baru 2016 yaitu pada tanggal 8 Januari 2016. Hal ini bertujuan untuk mengetahui perbedaan volume kendaraan pada masa liburan dan sesudahnya.

Hasilnya adalah sebagai berikut:

\section{Tabel 1.2}

Komparasi Jumlah Kendaraan Menurut Waktu I

\begin{tabular}{|c|c|c|c|c|c|c|}
\hline \multirow{3}{*}{ Pintu } & \multicolumn{4}{|c|}{$\begin{array}{c}23 / 12 / 2015 \\
\text { Roda } 2\end{array}$} & \multirow{2}{*}{\multicolumn{2}{|c|}{$\begin{array}{c}\text { Jumlah peningkatan } \\
(\%)\end{array}$}} \\
\hline & \multicolumn{2}{|c|}{$10.00-10.45$} & \multicolumn{2}{|c|}{$13.00-13.45$} & & \\
\hline & Masuk & \begin{tabular}{|l|} 
Keluar \\
\end{tabular} & Masuk & Keluar & Masuk & keluar \\
\hline Selatan & 715 & 331 & 839 & 522 & 17 & 57 \\
\hline Timur & 739 & 721 & 820 & 840 & 11 & 16 \\
\hline Barat & 685 & 790 & 815 & 887 & 19 & 12 \\
\hline \multicolumn{5}{|c|}{ Rata-rata } & 16 & 25 \\
\hline \multicolumn{7}{|c|}{ Roda 4} \\
\hline Selatan & 340 & 180 & 482 & 231 & 41 & 28 \\
\hline Timur & 250 & 295 & 342 & 372 & 37 & 26 \\
\hline Barat & 252 & 212 & 338 & 268 & 34 & 26 \\
\hline \multicolumn{5}{|c|}{ Rata-rata } & 37 & 27 \\
\hline
\end{tabular}

Sumber: Observasi Langsung, 2015

Pada tabel 1.2 dapat diketahui bahwa pada tanggal 23 Desember 2015, rata-rata peningkatan volume kendaraan roda dua yang masuk ke Ubud sebesar $16 \%$, sedangkan ratarata kendaraan roda dua yang keluar dari Ubud mengalami peningkatan sebesar $25 \%$. Rata-rata peningkatan volume kendaraan roda empat yang masuk ke Ubud adalah sebesar $37 \%$, sedangkan rata-rata kendaraan roda empat yang keluar dari Ubud mengalami peningkatan sebesar $27 \%$.

Tabel 1.3

Komparasi Jumlah Kendaraan Menurut Waktu II

\begin{tabular}{|c|c|c|c|c|c|c|}
\hline \multirow{3}{*}{ Pintu } & \multicolumn{4}{|c|}{$\begin{array}{c}08 / 01 / 2016 \\
\text { Roda } 2\end{array}$} & \multirow{2}{*}{\multicolumn{2}{|c|}{$\begin{array}{c}\text { Jumlah peningkatan } \\
(\%)\end{array}$}} \\
\hline & \multicolumn{2}{|c|}{$10.00-10.45$} & \multicolumn{2}{|c|}{$13.00-13.45$} & & \\
\hline & Masuk & Keluar & Masuk & Keluar & Masuk & keluar \\
\hline Selatan & 592 & 291 & 670 & 436 & 13 & 49 \\
\hline Timur & 607 & 620 & 677 & 712 & 11 & 14 \\
\hline Barat & 572 & 670 & 660 & 725 & 15 & 8 \\
\hline \multicolumn{5}{|c|}{ Rata-rata } & 13 & 24 \\
\hline \multicolumn{7}{|c|}{ Roda 4} \\
\hline Selatan & 254 & 149 & 363 & 183 & 42 & 23 \\
\hline Timur & 185 & 236 & 256 & 298 & 38 & 26 \\
\hline Barat & 181 & 174 & 247 & 214 & 36 & 23 \\
\hline \multicolumn{5}{|c|}{ Rata-rata } & 39 & 24 \\
\hline
\end{tabular}

Sumber: Observasi Langsung, 2015

Pada tabel 1.3 dapat diketahui bahwa pada tanggal 23 Desember 2015, rata-rata peningkatan volume kendaraan roda dua yang masuk ke Ubud sebesar $16 \%$, sedangkan ratarata kendaraan roda dua yang keluar dari Ubud mengalami peningkatan sebesar $25 \%$. Rata-rata peningkatan volume kendaraan roda empat yang masuk ke Ubud adalah sebesar $37 \%$, sedangkan rata-rata kendaraan roda empat yang keluar dari Ubud mengalami peningkatan sebesar $27 \%$.

Tabel 1.4

Komparasi Jumlah Kendaraan Menurut Musim I

\begin{tabular}{|c|c|c|c|c|c|c|c|}
\hline \multirow{4}{*}{ No } & \multirow{4}{*}{ Pintu masuk } & \multicolumn{2}{|c|}{ Roda 2} & \multicolumn{2}{|c|}{ Roda 2} & \multicolumn{2}{|c|}{ Roda 2} \\
\hline & & \multicolumn{2}{|c|}{$08 / 01 / 2016$} & \multicolumn{2}{|c|}{$23 / 12 / 2015$} & \multirow{2}{*}{\multicolumn{2}{|c|}{$\begin{array}{c}\text { Peningkatan } \\
\%\end{array}$}} \\
\hline & & \multicolumn{2}{|c|}{$10.00-10.45$} & \multicolumn{2}{|c|}{$10.00-10.45$} & & \\
\hline & & Masuk & Keluar & Masuk & Keluar & Masuk & Keluar \\
\hline 1 & Selatan & 592 & 291 & 715 & 331 & 20 & 14 \\
\hline 2 & Timur & 607 & 620 & 739 & 721 & 21 & 16 \\
\hline 3 & Barat & 572 & 670 & 685 & 790 & 20 & 18 \\
\hline \multicolumn{6}{|c|}{ Rata-rata } & 20 & 16 \\
\hline & & \multicolumn{2}{|c|}{$13.00-13.45$} & \multicolumn{2}{|c|}{$13.00-13.45$} & & \\
\hline & & Masuk & Keluar & Masuk & Keluar & & \\
\hline 1 & Selatan & 670 & 436 & 839 & 522 & 25 & 20 \\
\hline 2 & Timur & 677 & 712 & 820 & 840 & 21 & 18 \\
\hline 3 & Barat & 660 & 725 & 815 & 887 & 23 & 22 \\
\hline \multicolumn{6}{|c|}{ Rata-rata } & 23 & 20 \\
\hline
\end{tabular}

Sumber: Observasi Langsung, 2015

Dari tabel 1.4 dapat diketahui bahwa pada masa liburan, terjadi peningkatan volume kendaraan dibandingkan dengan hari biasa. Rata-rata peningkatan volume kendaraan untuk roda dua yang masuk ke Ubud pada pagi hari adalah sebesar $20 \%$, sedangkan untuk kendaraan roda dua yang keluar dari Ubud adalah sebesar $16 \%$. Rata-rata peningkatan volume kendaraan untuk roda dua yang masuk ke Ubud pada siang hari adalah sebesar $23 \%$, sedangkan untuk kendaraan roda dua yang keluar dari Ubud adalah sebesar $12 \%$.

Tabel 1.5

Komparasi Jumlah Kendaraan Menurut Musim II

\begin{tabular}{|c|c|c|c|c|c|c|c|}
\hline \multirow{4}{*}{ No } & \multirow{4}{*}{ Pintu masuk } & \multicolumn{2}{|c|}{ Roda 4} & \multicolumn{2}{|c|}{ Roda 4} & \multicolumn{2}{|c|}{ Roda 4} \\
\hline & & \multicolumn{2}{|c|}{ 08/01/2016 } & \multicolumn{2}{|c|}{$23 / 12 / 2015$} & \multirow{2}{*}{\multicolumn{2}{|c|}{$\begin{array}{c}\text { Peningkatan } \\
\%\end{array}$}} \\
\hline & & \multicolumn{2}{|c|}{$10.00-10.45$} & \multicolumn{2}{|c|}{$10.00-10.45$} & & \\
\hline & & Masuk & Keluar & Masuk & Keluar & Masuk & Keluar \\
\hline 1 & Selatan & 254 & 149 & 340 & 180 & 34 & 21 \\
\hline 2 & Timur & 185 & 236 & 250 & 295 & 35 & 25 \\
\hline 3 & Barat & 181 & 174 & 252 & 212 & 30 & 22 \\
\hline \multicolumn{6}{|c|}{ Rata-rata } & 33 & 23 \\
\hline & & \multicolumn{2}{|c|}{$13.00-13.45$} & \multicolumn{2}{|c|}{$13.00-13.45$} & & \\
\hline & & Masuk & Keluar & Masuk & Keluar & & \\
\hline 1 & Selatan & 363 & 183 & 482 & 231 & 32 & 26 \\
\hline 2 & Timur & 256 & 298 & 342 & 372 & 34 & 25 \\
\hline 3 & Barat & 247 & 214 & 338 & 268 & 37 & 25 \\
\hline \multicolumn{6}{|c|}{ Rata-rata } & 34 & 25 \\
\hline
\end{tabular}

Sumber: Observasi Langsung, 2015

Dari tabel 1.5 dapat diketahui bahwa pada masa liburan, terjadi peningkatan volume kendaraan dibandingkan dengan hari biasa. Rata-rata peningkatan volume kendaraan untuk roda empat yang masuk ke Ubud pada pagi hari adalah sebesar $33 \%$, sedangkan untuk kendaraan roda empat yang keluar dari Ubud adalah sebesar $23 \%$. Rata-rata peningkatan volume kendaraan untuk roda empat yang masuk ke Ubud pada siang hari adalah sebesar 
$34 \%$, sedangkan untuk kendaraan roda empat yang keluar dari Ubud adalah sebesar $25 \%$.

Dari tabel-tabel tersebut dapat diketahui bahwa volume kendaraan meningkat baik roda empat dan roda dua sama-sama mengalami peningkatan pada jam sibuk dan masa liburan. Namun uniknya, melalui tabel-tabel tersebut juga dapat diketahui bahwa pengguna jalan lebih sedikit yang memilih keluar Ubud melalui pintu selatan, sebaliknya pengguna jalan lebih suka memasuki Ubud dari pintu selatan.

\section{f. Persimpangan Jalan Terlalu Dekat}

Dari gambar 1.1, dapat diketahui bahwa ketika terjadi kemacetan pada persimpangan 1, maka akan terdapat antrian kendaraan di persimpangan 2 dan seterusnya sampai di persimpangan 3. Hal ini sering kali terjadi, bahkan menurut penuturan dari Kanit Lantas Polsek Ubud yaitu I Wayan Sudha:

"Ubud merupakan memiliki kunjungan wisatawan cukup tinggi. Kebanyakan wisatawan yang berkunjung menggunakan kendaraan roda empat. Selain itu, ruas jalan yang ada memiliki ukuran cukup sempit. Akibatnya ketika jumlah kendaraan yang masuk meningkat, maka persimpangan jalan akan menjadi titik temu dari kendaraan tersebut. Apabila terjadi kemacetan di salah satu persimpangan jalan, khususnya di beberapa titik rawan kemacetan jalan yaitu persimpangan BPD, persimpangan di Pasar Ubud dan persimpangan di Lapangan Ubud maka akan terjadi kemacetan yang mengular."

Dari penuturan I Wayan Sudha dapat dilihat bahwa persimpangan jalan tersebut berada di daerah rawan kemacetan lalu lintas di Kelurahan Ubud. Sehingga, dapat dikatakan bahwa terdapat korelasi kuat antara lokasi persimpangan jalan yang terlalu dekat dengan kemacetan yang terjadi.

Dalam kategori eksternal merupakan penyebab tambahan yang terjadi di luar wilayah Kelurahan Ubud. Meskipun dampaknya dirasakan sampai di dalam wilayah Kelurahan Ubud. Faktor tersebut adalah:

\section{a. Kemacetan di Beberapa Persimpangan}

Tidak hanya di dalam lingkungan Kelurahan Ubud saja yang terjadi kemacetan lalu lintas. Namun, beberapa wilayah lain di sekitar Kelurahan Ubud juga mengalami permasalahan yang sama, khususnya yang memiliki hubungan langsung sehingga semakin memperparah kemacetan yang terjadi di Kelurahan Ubud.
Penyebab kemacetan yang terjadi memiliki karakteristik yang sama dengan yang terjadi di Kelurahan Ubud, yaitu persimpangan jalan yang terlalu dekat.

Beberapa lokasi persimpangan yang dimaksud berada di lingkungan kelurahan lainnya, seperti persimpangan Jalan Nyuh Kuning dengan Jalan Raya Pengosekan, persimpangan Jalan Teges, dan persimpangan jalan di Banjar Lebah. Menurut penuturan Kanit Lantas Polsek Ubud yaitu I Wayan Sudha:

"Kemacetan kendaraan di beberapa
persimpangan jalan yang terjadi di luar
wilayah Kelurahan Ubud juga menjadi
penyebab terjadinya kemacetan di wilayah
Ubud. Beberapa titik tersebut adalah
persimpangan catus pata Teges, Banjar Lebah,
Nyuh Kuning, dan pom bensin Pengosekan."

Saat terjadi kemacetan panjang di persimpangan A, yang pada akhirnya mengular hingga ke persimpangan $B, C$ dan D. Tidak dapat dipungkiri lagi penumpukan jalan di persimpangan $\mathrm{C}$ dan $\mathrm{D}$ menyebabkan antrian dari dan ke dalam wilayah Kelurahan Ubud, yaitu melewati Jalan Raya Pengosekan menuju ke Jalan Monkey Forest dan Jalan Hanoman.

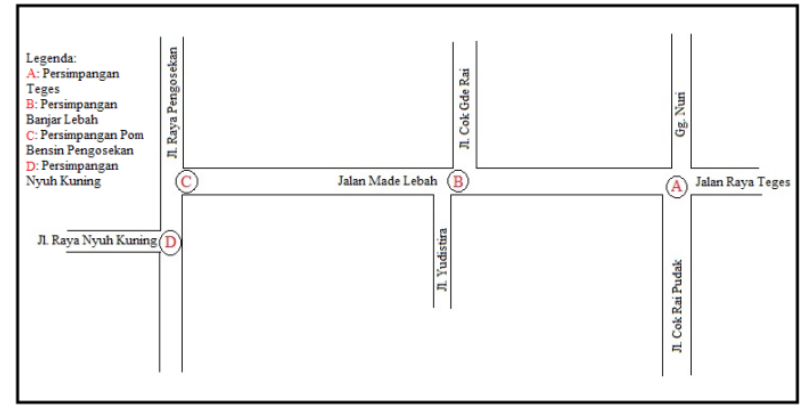

Gambar 1.2

Lokasi Persimpangan di Luar Wilayah Kelurahan Ubud

(Sumber: Observasi Langsung, 2016)

Apabila sudah terjadi kemacetan seperti itu, biasanya terjadi antrian panjang dari Jalan Hanoman yang akan keluar melalui pintu selatan Kelurahan Ubud. Akibatnya antrian panjang yang lainnya dapat mengular seperti pada sub bab terdahulu, yaitu terjadinya pola lingkaran kemacetan di Kelurahan Ubud.

Dengan demikian, pada dasarnya kemacetan lalu lintas yang terjadi di Kelurahan Ubud tidak dapat disamakan karakteristiknya dengan daerah-daerah lain di Bali yang juga sedang mengalami kemacetan. Masalah kemacetan di Ubud tidak serta merta hanya disebabkan oleh kapasitas jalan yang tidak 
sebanding dengan jumlah kendaraan yang melintas. Kemacetan lalu lintas di Ubud disebabkan oleh faktor-faktor baik internal maupun eksternal, sehingga untuk penyelesaiannya juga membutuhkan pendekatan yang berbeda sesuai dengan situasi dan kondisi di Kelurahan Ubud.

\subsection{Upaya Masyarakat Lokal Dalam Mengatasi Kemacetan}

Masyarakat lokal di Kelurahan Ubud tergolong dalam masyarakat aktif karena mampu untuk mengidentifikasi dinamika yang ada serta berusahan untuk mencari solusi atas dinamika tersebut. Sejauh ini, upaya yang direalisasikan oleh masyarakat lokal dalam mengatasi kemacetan lalu lintas di Kelurahan Ubud tidak lepas dari adanya sinergi dan integrasi yang terjadi antar elemen di dalam tubuh masyarakat lokal, khususnya dalam masing-masing desa pekraman.

Sejauh ini, masyarakat lokal dapat dikatakan mampu mengimplementasikan manajemen lalu lintas yang baik. Dilihat dari solusi yang sudah dapat direalisasikan, hal ini mencerminkan terdapat pola penyelesaian masalah dari sisi manifestation problems, solusi direalisasikan dari penyebab kemacetan yang terjadi sehari- hari. Inisiatif lokal yang sudah muncul tersebut layak mendapat apresiasi dari seluruh kalangan.

Beberapa solusi yang sudah direalisasikan diantaranya adalah sebagai berikut:

a. Sentral Parkir Pura Batukaru

Sentral parkir yang berada di areal Pura Batukaru sebelah utara Desa Ubud merupakan proyek masyarakat Desa Ubud yang difasilitasi oleh Pemerintah Kabupaten Gianyar. Pihak Puri Ubud adalah initiator sekaligus pendonor utama dari proyek ini. Sentral parkir berdiri di atas lahan seluas 78 are dan mampu menampung sebanyak 300 mobil. Dari hasil retribusi yang diterima pengelola parkir, sebagian besar masuk ke kas Pura Batukaru sehingga dapat digunakan untuk keperluan upacara dan sembahyang

b. Sentral Parkir Monkey Forest

Sentral parkir yang berada di sebelah timur Monkey Forest, Desa Padangtegal merupakan suatu megaproyek desa pakraman yang pada akhirnya akan terintegrasi dengan kawasan Monkey Forest. Sentral parkir dengan luas kurang lebih $7 \mathrm{H}$ tersebut apabila sudah selesai pengerjaanya, dapat menampung ribuan kendaraan baik roda empat dan roda dua. Meskipun sentral parkir ini dikelola oleh Desa Padangtegal, namun saat sudah beroperasi $100 \%$, masyarakat desa adat sepakat untuk menggunakannya bersama-sama dengan desa adat lain demi kepentingan Kelurahan Ubud. Rencananya seluruh kendaaran yang diparkir di badan jalan khususnya di kawasan Desa Padangtegal akan direlokasi ke sentral parkir ini.

c. Revitalisasi Rambu-Rambu Lalu Lintas dan Fasilitas Pejalan Kaki

Rambu-rambu lalu lintas yang ada di Kelurahan Ubud, baik di Desa Ubud dan Desa Padangtegal dalam dua tahun terkahir banyak dilakukan penambahan dan perbaikan oleh Dishub, Infokom Kabupaten Gianyar. Hal ini merupakan inisiatif masyarakat lokal karena berubah fungsinya beberapa tempat yang ada di Kelurahan Ubud. Diantaranya adalah rambu drop zone dan pick up zone bagi kendaraan yang melakukan penuruan dan penjemputan wisatawan. Kemudian rambu dilarang parkir, beberapa tempat yang dahulu digunakan untuk parkir terutama di daerah catus pata saat ini sudah tidak boleh lagi digunakan untuk parkir. Setelah itu adalah rambu dilarang berhenti dan rambu jalur satu arah.

Khusus di Desa Padangtegal sendiri, bahkan rambu-rambu baru yang ada di wilayah ini seluruhnya didanai oleh desa adat, bukan dari pemerintah. Revitalisasi fasilitas pejalan kaki yang sudah rusak juga dilakukan untuk memotivasi siapa saja yang sedang berada di Ubud agar lebih sering berjalan kaki demi mengurangi kepadatan lalu lintas.

d. Pengadaan Proyek Shuttle Bus

Salah satu upaya untuk mengurangi intensitas bis yang masuk ke Ubud, dilakukan pengadaan proyek shuttle bus dengan tujuan Dalem Puri - Puri Ubud. Bagi wisatawan yang ingin menggunakan Shuttle, akan dikenakan tarif sebesar Rp. 50.000 sekali jalan, shuttle juga akan melakukan penjemputan apabila diminta. Dengan begitu, hasil dari pemasukan shuttle sebagian dapat menjadi pemasukan untuk kas desa adat.

Upaya ini berhasil atas sinergi dari para anggota FKDPU, dengan didanai oleh salah satu anggotanya yaitu Dewa Aji Widia, maka proyek shuttle bus ini dapat berjalan dalam kurun waktu 6 bulan terkahir. Saat ini armada masih berjumlah 4 kendaraan, namun dalam waktu kedepan apabila semakin banyak wisatawan yang 
tertarik maka akan ditambah jumlahnya. Pada saatnya nanti, shuttle tersebut rencananya akan diintegrasikan dengan sentral-sentral parkir lainnya.

e. Pengaturan Arus Lalu Lintas

Beberapa jalan yang ada di Kelurahan Ubud seperti Jalan Hanoman, Jalan Monkey Forest dan sebagaian Jalan Raya Ubud dahulu merupakan jalan yang dapat dilalui secara dua arah oleh kendaraan. Namun, saat ini seluruh jalan tersebut sudah menjadi satu arah untuk mengurangi kemacetan lalu lintas. Masyarakat berinisiatif agar merubah jalur dua arah tersebut menjadi satu arah untuk mengurangi kepadatan lalu lintas.

Pemerintah dibantu oleh kepolisian dan pecalang melakukan rekayasa lalu lintas selama beberapa waktu agar pengguna jalan terbiasa dengan perubahan baru tersebut. Hasilnya di ruas jalan tersebut saat ini hanya bisa dilalui dengan satu arah, sebagian badan jalan akhirnya dimanfaatkan untuk parkir kendaraan.

\section{PENUTUP}

Minimnya peran aktif pemerintah daerah dalam mengatasi kemacetan lalu lintas di Kelurahan Ubud, ternyata justru membangkitkan inisiatif lokal untuk berusaha mandiri dalam rangka mengatasi masalah tersebut. Inisiatif lokal tersebut terealisasi dalam beberapa proyek yang dikerjakan oleh masyarakat lokal, bahkan sebagian besar biaya yang dikeluarkan menelan dana pribadi. Namun, ternyata peran pemerintah yang terlihat menciut bukan tanpa alasan. Dominasi dari keluarga Puri Ubud yang besar merupakan salah satu alasan pemerintah tidak terlalu ikut campur dengan dinamika di wilayah Ubud.

Bagaimanapun juga, kemacetan yang tak kunjung terselesaikan ini disinyalir masih minimnya kerja sama antara masyarakat lokal dan pemerintah daerah. Hal ini menjadi pembelajaran bahwa peran aktif pemerintah masih diperlukan dalam kasus Ubud dengan kemacetannya. Pemerintah bisa memulai langkah aktifnya dengan membuatkan satu masterplan kemana arah Ubud akan berjalan, kemudian dibuatkan juga kebijakan yang lebih berkelanjutan serta implementasi hukum agar tidak terjadi pelanggaran di lapangan.

Kemudian mulai menentukan status Kelurahan Ubud sebagai desa yang berskala internasional, apakah akan dikelola seperti desa kelurahan pada umumnya ataukah diberi perangkat dan kapasitas yang lebih besar mengingat kompleksnya tatanan masyarakat lokal seperti adanya kekuatan besar yang dimiliki oleh keluarga puri Ubud.

Kemudian, perlunya pemerintah daerah untuk duduk bersama-sama dengan masyarakat lokal, dalam hal ini dihadapkan dengan keluarga puri, agar terjadi sinergitas dalam berbagai tujuan yang akan ditetapkan. Jadi, seluruh tindakan yang diambil dapat selaras dan sesuai dengan keinginan masyarakat dan pemerintah. Pentingnya pertemuan antara titik temu tersebut agar dapat menyeimbangkan peran di antara keduanya, agar tidak terjadi ketimpangan dan ketidakseimbangan.

Banyak contoh dari peran dan kerjasama yang baik antara masyarakat lokal dan pemerintah dengan porsi yang seimbang, pada akhirnya menimbulkan efek yang lebih besar dan efektif. Begitu juga di Kelurahan Ubud, kembalinya peran negara akan lebih menyeimbangkan dominasi dari masyarakat lokal. Sehingga untuk menyelesaikan permasalahan kemacetan yang sedang terjadi, peran aktif yang lebih besar dari pemerintah akan lebih mengefektifkan usaha yang sudah berjalan dan di masa mendatang.

\section{DAFTAR PUSTAKA}

Anonim. 1997. Manual Kapasitas Jalan Indonesia (MKJI). Jakarta: Direktorat Jenderal Bina Marga.

Boediningsih, W. 2011. Dampak Kepadatan Lalu Lintas Terhadap Polusi Udara Kota Surabaya. Jurnal 20, h. 122-132.

Poloma, Margaret M. Sosiologi Kontemporer. Jakarta: Rajagrafindo Persada.

Handoko, T. Hani. 1993. Manajemen. Jakarta: EPFD.

Stoner, James A. F. dan Wankel, Charles. 1986. Perencanaan Dan Pengambilan Keputusan Dalam Manajemen. Jakarta: Rineka Cipta.

Deardorff, Dale S. and Williams, Greg. 2006. Synergy Leadership in Quantum Organizations. Fesserdorff Consultants.

Priyanto, Sigit. 2010. Peran Manajemen Lalu Lintas Dalam Mengurangi Kemacetan. Yogyakarta: UGM 